\title{
Response of Asian Marine Fishery to ENSO Related SST for the Period 1982-2016
}

\author{
Jing $\mathrm{Li}^{1}$ and Min Shao ${ }^{2 *}$ \\ ${ }^{1}$ The Chinese University of Hong Kong, China \\ ${ }^{2}$ Atmospheric \& Planetary Science, Hampton University, USA
}

Submission: January 07, 2019; Published: February 22, 2019

Corresponding author: Min Shao, Atmospheric \& Planetary Science, Hampton University, Hampton, VA, USA

\begin{abstract}
The relationships between Asian marine fishery and ENSO related sea surface temperature (SST) during the 1982-2016 are explored using the constructed SST data and global fishery statistics. Results show that high yields of aquatic plants, crustaceans, diadromous fishes and miscellaneous aquatic animals are closely related to very strong El Nino events; high yields of molluscs, marine fishes, miscellaneous aquatic animal products and aquatic mammals have connections with strong La Niña events. Therefore, ENSO related SST can be determined as a valuable indicator for Asian marine fishery.
\end{abstract}

Keywords: Aquatic plants; Diadromous fishes; Asian marine fishery; Climate changes; Fluctuations; Atmospheric oscillation; El Nino-Southern Oscillation; Marine fishery resources; Sea Surface Temperature; International Comprehensive Ocean-Atmosphere Dataset; Food and Agriculture Organization; Miscellaneous aquatic animals; La Niña events; Pacific Decadal Oscillation

\section{Introduction}

Fishery resources are strongly affected by the environmental conditions in various scales such as SST, oceanic frontal boundaries, upwelling, currents and other circulation patterns [1-3]. Satellite based observations, which can provide large scale (global) information, have been widely used as tracers or predictors for potential marine fishing regions [1,4-6]. It has been widely studied that the SST plays an important role in the distribution, recruitment and number of species of fishery resources [7], showed that the SST anomalies is closely related to the number of fish species but various in different oceans. Due to the climate changes in recent decades, large fluctuations were observed in the atmospheric as well as oceanic environments [8]. As Earth's most influential naturally-recurring sea and atmospheric oscillation, El Nino-Southern Oscillation (ENSO) results in widespread changes in the climate and ecosystem [9-11]. In nowadays, satellite records are long enough for the analysis of the relations between fishery resources and climate phenomenon with advantages in global coverage by using polarsatellites. This paper is aimed to demonstrate the relations between marine fishery resources over Asian coastal lines and ENSO.

Data

The global monthly Extended Reconstructed Sea Surface Temperature (ERSST, version 5) derived from the International
Comprehensive Ocean-Atmosphere Dataset (ICOADS) during the period 1982-2016 is used in this study [12]. The ERSST which is constructed with multiple data sets from ships, buoys, satellites (since 1982) et al. has a horizontal resolution of $2^{\circ} \times$ $2^{\circ}$. For fishery data, the global statistic captures from the Food and Agriculture Organization (FAO) of the United Nations is used [13]. The FAO fish capture data is only based on available data set on the global fish catch. Capture production is classified into 14 major marine fishing areas according to the marine area where caught and the nine families of FAO aquatic species encompassing the waters of the Atlantic, Indian, and Pacific oceans.

\section{Results}

We first examine the changes of various aquatic products based on detrended and normalized time-series of Asian marine fishery in Figure 1. The time-series of aquatic products show significant interannual variability during 1982-2016. To highlight the relationships between Asian marine fishery and ENSO related SST, those years with extreme fishery landings based on the threshold $( \pm 1.0)$ in all time-series are selected (Table 1). We also mark extreme ENSO years on both El Niño and La Niña periods defined as 5 consecutive overlapping 3-month periods at above the $+0.5^{\circ}$ SST anomaly (in the Niño 3.4 region, $5^{\circ} \mathrm{N}-5^{\circ} \mathrm{S}, 120^{\circ}-170^{\circ} \mathrm{W}$ ) for warm (El Niño) events and at or 
below the $-0.5^{\circ}$ SST anomaly (SSTA) for cold (La Niña) events. The SSTA threshold is further divided into weak (with a 0.5 to 0.9 SST anomaly), moderate (1.0 to 1.4 ), strong (1.5 to 1.9 ) and very strong $(\geq 2.0)$ events based on the golden gate weather service (http://ggweather.com/enso/oni.htm). Here, we mark very strong El Niño events and strong La Niña events, respectively.

(a)

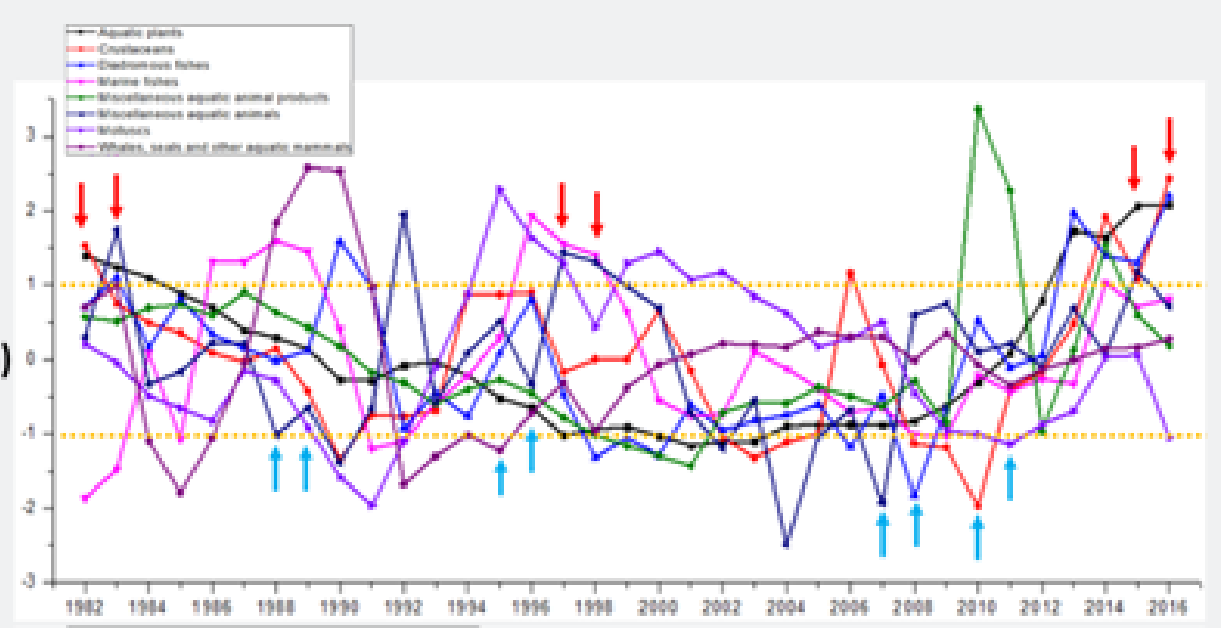

(b)

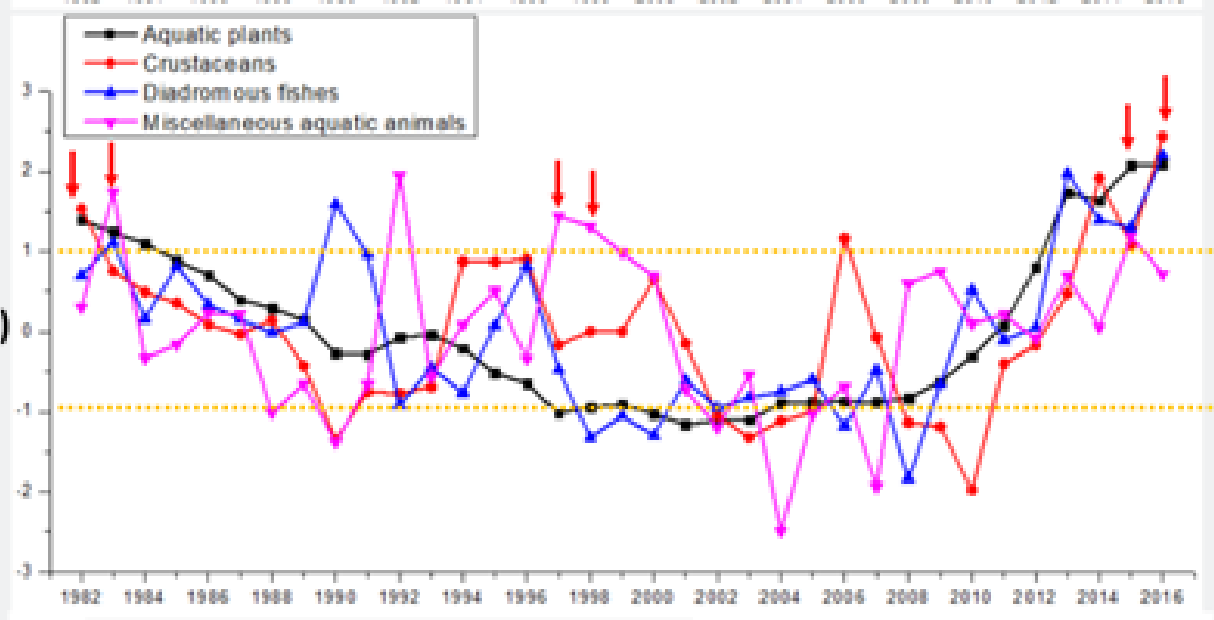

(c)

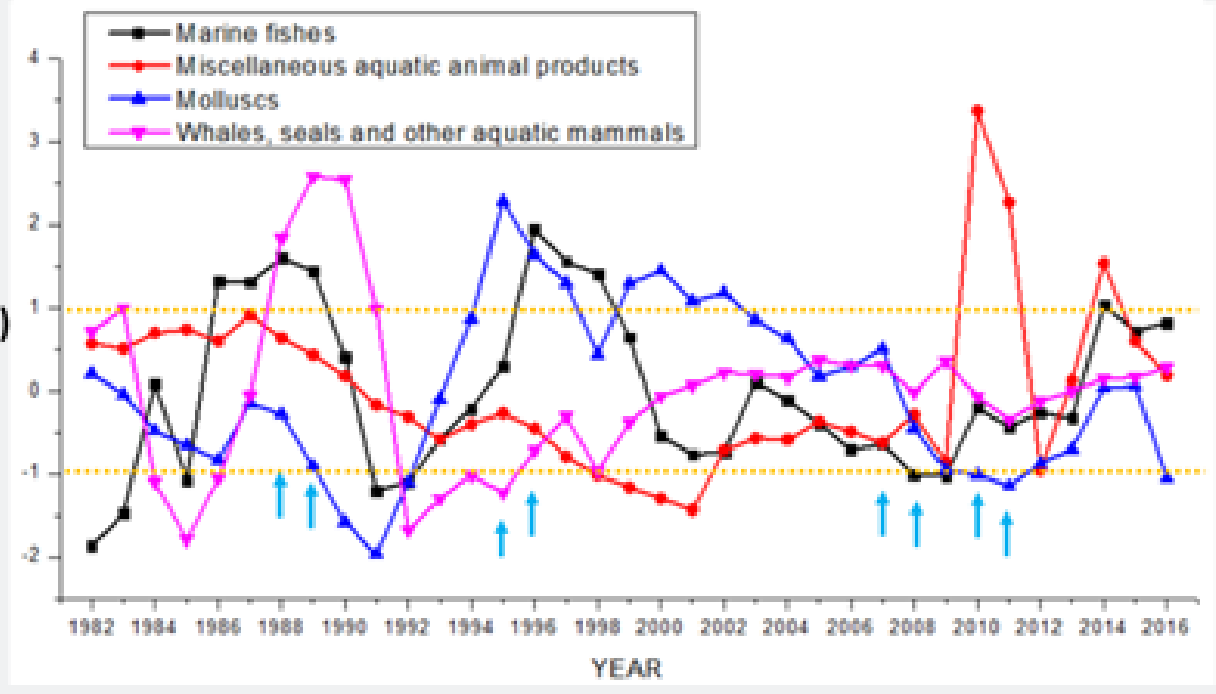

Figure 1: Changes in various Asian aquatic products during 1982-2016.

(a) All kinds of aquatic products (b) El Niño-related aquatic products (c) La Niña-related aquatic products. Red arrows indicate El Niño years, blue arrows indicate La Niña years and yellow dash lines represent thresholds for picking composite extreme years. 
Table 1: Composite extreme years based on time-series of fishery yields

\begin{tabular}{|c|c|c|c|}
\hline & Type & High yield years & Low yield years \\
\hline \multirow{4}{*}{ El Niño-related } & Aquatic plants & $1982^{*}, 1983^{*}, 1984,2013,2014,2015^{*}$ & $1997 *, 2000,2001,2002,2003$ \\
\hline & Crustaceans & $1982^{*}, 2006,2014,2015^{*}, 2016^{*}$ & $\begin{array}{c}1990,2002,2003,2004,2005,2008+ \\
2009,2010 \dagger\end{array}$ \\
\hline & Diadromous fishes & $1983^{*}, 1990,2013,2014,2015^{*}, 2016^{*}$ & $1998^{*}, 1999,2000,2006,2008 \dagger$ \\
\hline & Miscellaneous aquatic animals & 1983*, 1992, 1997*, 1998*, 2015* & $1988 \dagger, 1990,2002,2004,2005,2007 \dagger$ \\
\hline \multirow{4}{*}{ La Niña-related } & Molluscs & $\begin{array}{c}1995+, 1996+, 1997^{*}, 1999,2000 \\
2001,2002\end{array}$ & $1990,1991,1992,2010 \dagger, 2011 \dagger, 2016^{*}$ \\
\hline & $\begin{array}{l}\text { Whales, seals and other aquatic } \\
\text { mammals }\end{array}$ & 1988†, 1989†, 1990 & $\begin{array}{c}1984,1985,1986,1992,1993,1994, \\
1995 \dagger\end{array}$ \\
\hline & Marine fishes & $\begin{array}{c}\text { 1986, 1987, 1988†, 1989†, 1996†, } \\
1997^{*}\end{array}$ & $\begin{array}{c}1982 *, 1983 *, 1985,1991,1992 \\
2008+, 2009\end{array}$ \\
\hline & Miscellaneous aquatic animal products & $2010 \dagger, 2011 \dagger, 2014$ & 1998*, 1999, 2000, 2001 \\
\hline
\end{tabular}

The years with "*” and "†" are Very Strong El Niño years and Strong La Niña years, respectively.

Table 1 shows that high yields of aquatic plants, crustaceans, diadromous fishes and miscellaneous aquatic animals are all closely related to very strong El Niño events (over half of the events are dropped in the very strong category). As for their low yield years, crustaceans and miscellaneous aquatic animals have more relations to strong La Niña events. In contrast, diadromous fishes do not show significant relations to the ENSO events. It shows a significant asymmetric impact of ENSO on aquatic plants and diadromous fishes, but for crustaceans and miscellaneous aquatic animals. In addition, high yields of molluscs, marine fishes, miscellaneous aquatic animal products, aquatic mammals, and low yields of molluscs are all closely related to Strong La Niña events. Only low yields of marine fishes show strong relations to very strong El Niño events. Other marine products have little connection with ENSO during their low yield years. Therefore, these eight types of aquatic products can be classified into two categories according to the frequency of ENSO events during their high yield years: El Niñorelated type (aquatic plants, diadromous fishes, crustaceans and miscellaneous aquatic animals) and La Niña-related type (molluscs, marine fishes, miscellaneous aquatic animal products and whales, seals and other aquatic mammals).

To investigate the spatial patterns of SSTA during extreme yield years of Asian marine fishery, the composite analysis is conducted for ERSST. Figure 2 shows the composite SSTA during extreme years of Asian fishery yields. Figure 2(a, c, e, g, f, j) show the typical El Niño pattern during high yield years of aquatic plants, crustaceans, diadromous fishes and miscellaneous aquatic animals respectively and low yield years of miscellaneous aquatic animals and molluscs; Figure 2(b, d, i, k, m) show the La Niña pattern in the periods of low yield years of aquatic plants, diadromous fishes and high yield years of molluscs, miscellaneous aquatic animal products and aquatic mammals. There is no significant ENSO signal in Figure 2(h, l, n, $o, p)$ because comparable El Niño and La Niña events are both used to construct the SST which offset their respective spatial patterns in SSTA composition fields.

\section{Conclusion and Discussion}

In the present study, the relationships between the Asian fishery landings and the ENSO related SST are explored using the ERSST and the FAO global fishery catch data sets. Results indicate that high yields of aquatic plants, crustaceans, diadromous fishes and miscellaneous aquatic animals are closely related to very strong El Niño events; while high yields of molluscs, marine fishes, miscellaneous aquatic animal products and aquatic mammals have connections with strong La Niña events. This demonstrates that the ENSO is an important factor that influences the yields of Asian fishery; and it is valuable in predicting yield, developing production plan, fully taking advantage of climate and reducing losses from climate disasters.

Furthermore, there is seemingly a Pacific Decadal Oscillation (PDO) pattern in Figure 2 because of the significant negative SSTA over Northwest Pacific, especially for Figure 2(a, c, e, g). PDO and ENSO influence SST, sea level pressure, etc. in very similar way. The most obvious difference between them is the time scale. Additionally, PDO primarily affects the North Pacific region while ENSO primarily affects the climate of lower latitudes. Therefore, the relationships between Asian fishery and PDO need further research. 

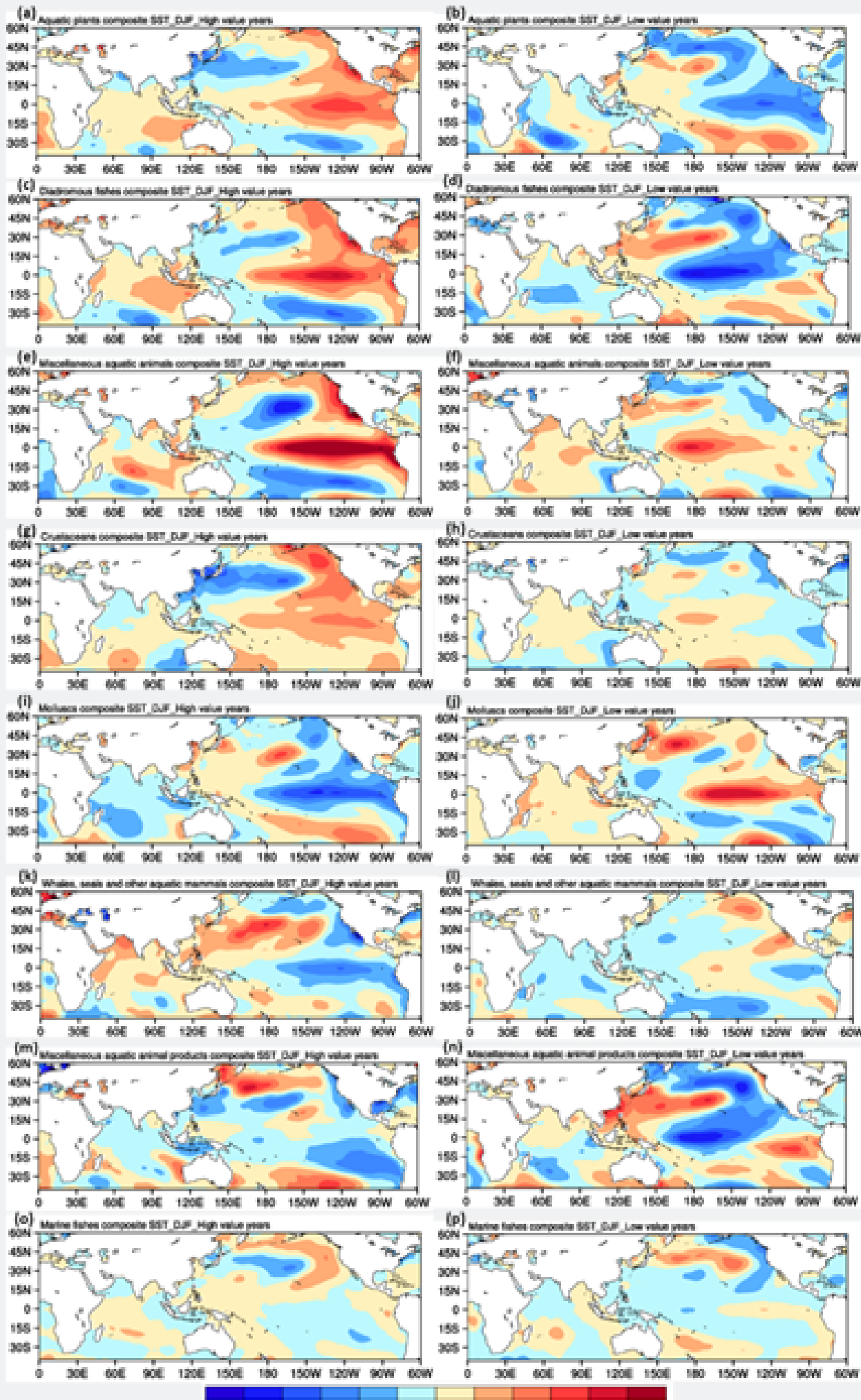

Figure 2: Composite SSTA (unit: ${ }^{\circ} \mathrm{C}$ ) during extreme years of fishery yields. Figures in left column are high yields years, and in right column are low yields years. (a) and (b) Aquatic plants, (c) and (d) Diadromous fishes, (e) and (f) Miscellaneous aquatic animals, (g) and (h) Crustaceans, (i) and (j) Molluscs, (k) and (I) Whales, seals and other aquatic mammals, (m) and (n) Miscellaneous aquatic animal products, (o) and $(p)$ Marine fishes. 


\section{Acknowledgement}

This work was supported by the JPSS Proving Ground Risk Reduction project, the Hampton University Center for Atmospheric Research and Education (HUCARE) and the ViceChancellor's Discretionary Fund of the Chinese University of Hong Kong.

\section{References}

1. Solanki HU, M Raman, B Kumari, RM Dwivedi, A Narain (1998) Seasonal trends in the fishery resources off Gujarat: Salient observation using NOAA AVHRR. Indian Journal of Marine Sciences 27(3): 438-442.

2. Waluda CM, PN Trathan, PG Rodhouse (1999) Influence of oceanographic variability on recruitment in the Illex argentines (Cephalopoda: Ommastrephidae) fishery in the South Atlantic. Marine Ecology Progress Series 183: 159-167.

3. Shao M, J Xu, A M Powell, F Kogan, W Guo (2015) Global land vegetation and marine fishery responses to atmospheric and oceanic decadal variability. International Journal of Remote Sensing 36(21): 55235536.

4. Solanki H U, R M Dwivedi, S R Nayak, V S Somvanshi, D K Gulati, et al. (2003) Fishery forecast using OCM chlorophyll concentration and AVHRR SST: validation results off Gujarat coast, India. International Journal of Remote Sensing 24(18): 3691-3699.

5. Choudhury S B, B Jena, M V Rao, K H Rao, V S Somvanshi, et al. (2007) Validating of integrated potential fishing zone (IPFZ) forecast using satellite-based chlorophyll and sea surface temperature along the coast of India. International Journal of Remote Sensing 28(12): 26832693.
6. Zhang X, SI Saitoh, T Hirawake (2017) Predicting potential fishing zones of Japanese common squid (Todarodes pacificus) using remotely sensed images in coastal waters of south-western Hokkaido, Japan. International Journal of Remote Sensing 38(21): 6129-6146.

7. Santos AMP, AFG Fiuza, RM Laurs (2006) Influence of SST on catches of swordfish and tuna in the Portuguese domestic longline fishery. International Journal of Remote Sensing 27(15): 3131-3152.

8. Waluda CM, C Yamashiro, PG Rodhouse (2006) Influence of the ENSO cycle on the light-fishery for Dosidicus gigas in the Peru Current: An analysis of remotely sensed data. Fisheries Research 79(1-2): 56-63.

9. Rabitah DN, AM Fadzil, MM Aidy (2019) Dynamic of ENSO towards upwelling and thermal front zone in the east coast of Peninsular Malaysia. Acta Oceanologica Sinica 38(1): 48-60.

10. Li J, K Fan, Z Xu (2016) Asymmetric response in Northeast Asia of summer NDVI to the preceding ENSO cycle. Climate Dynamics 47(910): $2765-2783$.

11. Li J, K Fan, L Zhou (2017) Satellite Observations of El Niño Impacts on Eurasian Spring Vegetation Greenness during the Period 1982-2015. Remote Sensing 9(7): 628.

12. Huang BY, PW Thorne, VF Banzon, T Boyer, G Chepurin, et al. (2017) NOAA Extended Reconstructed Sea Surface Temperature (ERSST), Version 5. NOAA National Centers for Environmental Information. doi:10.7289/V5T72FNM.

13. Froese R, D Zeller, K Kleisner, D Pauly (2012) What Catch Data Can Tell Us about the Status of Global Fisheries. Marine Biologiy 159(6): 12831292.

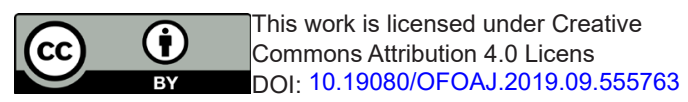

\section{Your next submission with Juniper Publishers will reach you the below assets}

- Quality Editorial service

- Swift Peer Review

- Reprints availability

- E-prints Service

- Manuscript Podcast for convenient understanding

- Global attainment for your research

- Manuscript accessibility in different formats

( Pdf, E-pub, Full Text, Audio)

- Unceasing customer service

Track the below URL for one-step submission https://juniperpublishers.com/online-submission.php 